\title{
Gene Expression Profile of Serial Samples of Transformed B-Cell Lymphomas
}

\author{
Sven de Vos, Wolf-Karsten Hofmann, Thomas M. Grogan, Utz Krug, \\ Mathew Schrage, Thomas P. Miller, Jonathan G. Braun, William Wachsman, \\ H. Phillip Koeffler, and Jonathan W. Said
}

Division of Hematology/Oncology (SdV), Department of Pathology and Laboratory Medicine (SdV, MS, JGB, JWS), UCLA School of Medicine, and Department of Hematology/Oncology (SdV, W-KH, UK, HPK), Cedars Sinai Medical Center, Los Angeles, and Medical and Research Services (WW), VASDHS, San Diego, and Division of Hematology/ Oncology and Cancer Center (WW), UCSD School of Medicine, La Jolla, California; and Departments of Pathology (TMG) and Hematology/Oncology (TPM), University of Arizona, Tucson, Arizona

\begin{abstract}
SUMMARY: Follicular lymphoma $(\mathrm{FL})$ is characterized by a continuous rate of relapse and transformation to a high-grade lymphoma, usually diffuse large B-cell lymphoma (DLBCL), associated with a dismal prognosis and a poor response to conventional chemotherapy. The progression of indolent to aggressive FL is accompanied by the successive accumulation of recurrent chromosomal defects, but the resultant alterations of gene expression are largely unknown. To expand the understanding of the pathogenesis of FL transformation, we initially performed oligonucleotide microarray analyses using Affymetrix HuFL chips on five cases with matched snap-frozen lymph nodes before and after transformation. Expression data were analyzed using the Affymetrix Microarray Suite 4.0 and Genespring 4.0. Thirty-six genes with increased expression and 66 genes with decreased expression associated with transformation were identified and functionally classified. The expression of differentially expressed genes was confirmed by real-time quantitative RT-PCR (QRT-PCR) using a total of seven matched pairs and an additional five FL and five unrelated DLBCL. In addition, selected genes were further analyzed by QRT-PCR or immunohistochemistry using a large, unrelated series of FL (grades 1 to 3 ) as well as transformed and de novo DLBCL (total of 51 samples). The microarray results correlated with the protein expression data obtained from samples at the time of initial diagnosis and transformation. Furthermore, the expression of 25 candidate genes was evaluated by QRT-PCR with a 78\% confirmation rate. Some of the identified genes, such as nucleobindin, interferon regulatory factor 4 , and tissue inhibitor of metalloproteinases 1, are already known to be associated with high-grade non-Hodgkin's lymphoma. Novel candidate genes with confirmed increased and decreased expression in transformed DLBCL include ABL2 and NEK2, and PDCD1 and VDUP1, respectively. In summary, this study shows that transformation of FL to DLBCL is associated with a distinct set of differentially expressed genes of potential functional importance. (Lab Invest 2003, 83:271-285).
\end{abstract}

$F$ ollicular lymphoma (FL), one of the most common characterized by a long median survival of 8 to 10 years and a continuous pattern of relapse (Horning, 2000). The probability of transformation to a higher grade lymphoma is $22 \%$ at 5 years and $31 \%$ at 10 years after diagnosis (Bastion et al, 1997), with a median duration of survival after transformation of 22

\section{DOI: 10.1097/01.LAB.0000053913.85892.E9}

Received October 30, 2002.

This work was supported in part by the Neil Ruzic Fund and the Lymphoma Research Foundation of America and National Institutes of Health Grant NIH-UOICA66533-02. SdV is a fellow of the UCLA Specialty Training and Advanced Research (S.T.A.R.) program, and WKH is a recipient of a scholarship (HO2207/1-1) from the Deutsche Forschungsgemeinschaft. HPK is a member of the Jonsson Comprehensive Cancer Center and holds the endowed Mark Goodson Chair of Oncology Research at Cedars-Sinai Medical Center/UCLA School of Medicine.

Address reprint requests to: Dr. S. de Vos, Division of Hematology/Oncology, UCLA Medical Center, 650 Charles E. Young Drive S., 11-266 Factor Building, Los Angeles, CA 90095-1678. E-mail:devos@mednet.ucla.edu months (Yuen et al, 1995) because of refractoriness to therapy (Bastion et al, 1997; Horning, 1994).

Similar to oncogenesis in solid tumors, lymphomagenesis is considered to be a multistep process. After transformation, FL has a variable histology and phenotype, with diffuse large B-cell lymphoma (DLBCL) being most common, followed by Burkitt-like lymphoma (Aventin et al, 1990; Yano et al, 1992) and blastic morphology (Come et al, 1980; Weiss and Warnke, 1985). Clonality studies strongly suggest that the majority of DLBCLs arising in FL are clonally related to the initial lymphoma (Matolcsy et al, 1999; Traweek et al, 1993; Zelenetz et al, 1991). The translocation (14;18)(q32;q21), the genetic hallmark of FL, is detectable in some normal individuals (Limpens et al, 1995) and is not sufficient to cause FL (Strasser et al, 1990), suggesting that additional genetic events are required (Knutsen, 1997; McDonnell and Korsmeyer, 1991). Several molecular or genetic events have been associated with transformation of $\mathrm{FL}$, including p53 mutations (Lo Coco et al, 1993; Sander et al, 1993), MYC (De Jong et al, 1988; Yano et al, 1992), and REL 
gene activation (Goff et al, 2000; Houldsworth et al, 1996; Joos et al, 1996; Rao et al, 1998), rearrangements of both mbr and mcr regions of BCL-2 (Nomdedeu et al, 1998), somatic mutations of the translocated BCL-2 gene (Matolcsy et al, 1996; Ottensmeier et al, 1998; Stamatopoulos et al, 2000), as well as deletions of 9p21 involving p15 (INK4b) and p16 (INK4a) (Elenitoba-Johnson et al, 1998; Pinyol et al, 1998; Stranks et al, 1995). Cytogenetic studies identified nonrandom chromosomal abnormalities in FL that correlated with survival, response to treatment, and risk of transformation (Tilly et al, 1994). Also, comparative genomic hybridization showed an unexpected high incidence of chromosomal imbalances and gene amplifications in FL (Bentz et al, 1996). Gene expression profiling has been very useful for studying NHL. For example, Clusterin has been identified as a new diagnostic marker for anaplastic large-cell lymphomas (Wellmann et al, 2000). Also, de novo DLBCLs has been separated into two subgroups, a germinal center-like DLBCL with a better prognosis and an activated B-cell-like DLBCL with a worse clinical outcome (Alizadeh et al, 2000). In addition, microarray profiling demonstrated that the $t(14 ; 18)$ defines a unique set of DLBCL with a germinal center B-cell expression profile (Huang et al, 2002).

Taken together, different pathways can lead to transformation of FL. Oligonucleotide microarray analysis is a robust technique to examine multiple cellular pathways. Using initially matched, microdissected samples that evolved into a high-grade lymphoma from the same individuals, we profiled gene expression associated with progression from low- to high-grade lymphomas. Changes in gene expression were validated in a large number of genes using both quantitative real-time PCR (QRT-PCR) and immunohistochemistry of an extensive collection of well-characterized lymphomas, resulting in the identification of cellular pathways that may become aberrant during progression of FL.

\section{Results}

\section{Distribution of Gene Expression in Transformed B-Cell Lymphoma}

Table 1 shows the distribution of differentially expressed genes in transformed B-cell lymphomas calculated with the Genespring software. Twenty-seven genes showed at least a 3-fold increased expression in at least three of five cases to an average difference value of five times the background numbers. Sixtythree genes showed at least a 3-fold decreased expression in at least three of five cases from an average difference value of five times the background numbers. Together with genes that were labeled increased or decreased by the Affymetrix software, we selected a total of 36 genes with increased expression and 66 genes with decreased expression including 3 duplicate genes. All selected genes are shown as a hierarchical cluster in Figure 1. Before concentrating on the above group of highly selected genes, we confirmed four additional genes (ABL2/ARG, HOXA1, NEK2, and TPRC/PRCC) that are also shown in Figure 1.

\section{Classification of Differentially Expressed Genes in Transformed B-Cell Lymphomas}

Table 2 summarizes the list of differentially expressed genes according to the above strict selection criteria. Thirteen T cell-specific genes and four dendritic cellspecific genes showed decreased expression. We found 28 genes with increased expression that are associated with cell proliferation and metabolism. This is in concordance with a higher cell proliferation rate in the high-grade lymphomas. Three transcription factors were increased and six apoptosis-related genes decreased. In addition, a mixed group of 6 genes with increased expression and 30 genes (3 duplicates) with decreased expression included potential candidate genes. A statistical analysis of this data set is constrained by the low case numbers and the nonuniform changes for many of the identified genes. Genes with a significance of $p<0.05$ are indicated.

\section{Correlation of Diagnostic Immunohistochemistry Results and Microarray Gene-Expression Data}

All lymphomas expressed BCL2 and CD20 with the exception of Case 1, which lost CD20 expression after transformation. The microarray results correlated well with the protein expression data obtained at the time of initial diagnosis and transformation, exemplified by vascular endothelial growth factor, CD20, CD22, and c-MYC expression in Case 1 (Table 3). Because of limited amounts of available tissue, no material for

Table 1. Distribution of differentially expressed genes in matched samples of transformed B-cell lymphomas before and after transformation to a high-grade NHL

\begin{tabular}{|c|c|c|c|c|c|c|}
\hline \multirow[b]{2}{*}{ Fold change } & \multicolumn{3}{|c|}{ Up } & \multicolumn{3}{|c|}{ Down } \\
\hline & $\times 10$ & $\times 3$ & $\times 2$ & $\div 2$ & $\div 3$ & $\div 10$ \\
\hline \multicolumn{7}{|l|}{ Frequency } \\
\hline 5 of 5 cases & 0 & 0 & 2 & 1 & 1 & 1 \\
\hline 4 of 5 cases & 0 & 7 & 41 & 53 & 25 & 7 \\
\hline 3 of 5 cases & 25 & $135\left(27^{a}\right)$ & 367 & 380 & $190\left(63^{a}\right)$ & 77 \\
\hline
\end{tabular}

Twenty-seven genes showed at least a 3-fold increased expression in at least three of five cases to an average difference value of five times the background numbers. Sixty-three genes showed at least a 3-fold decreased expression in at least three of five cases from an average difference value of five times the background numbers. Data restriction: absolute raw data restriction for differentially expressed genes is at least one times or 5 -fold $\left({ }^{a}\right)$ of background value. 

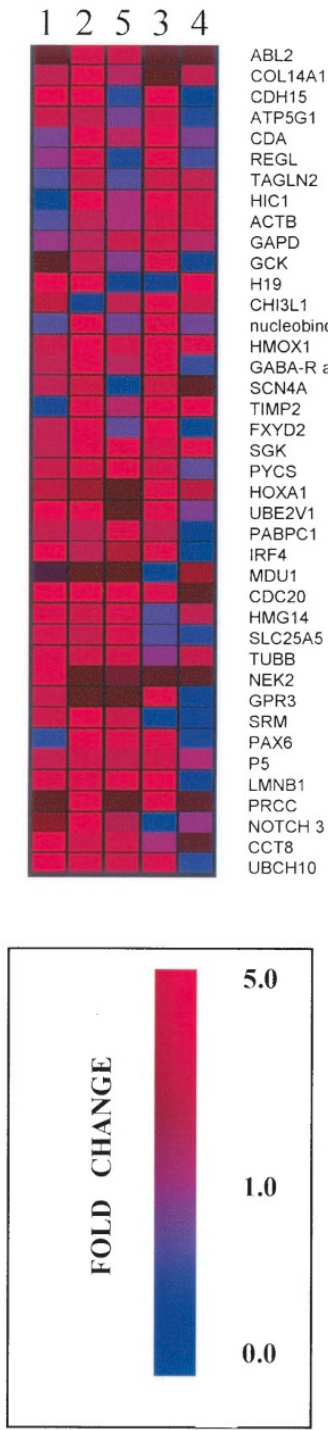
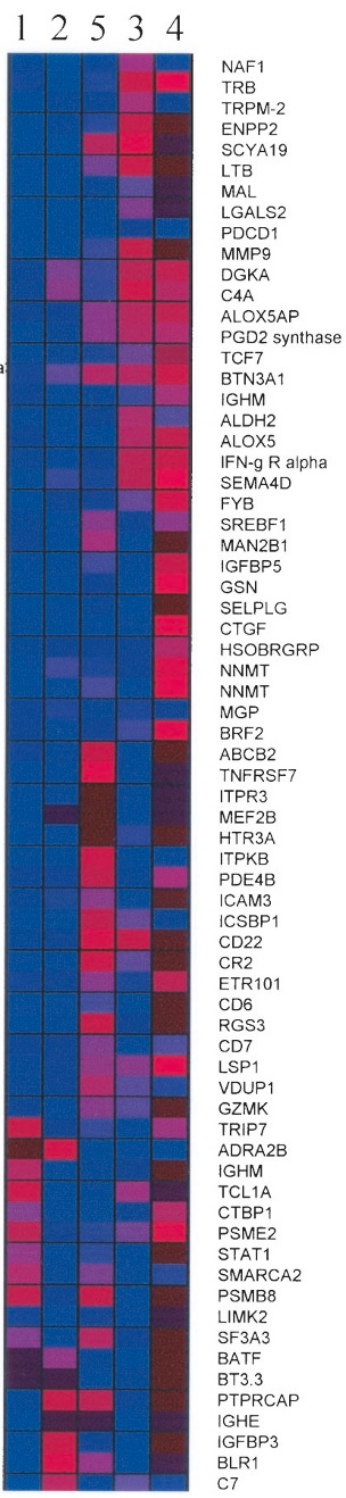

Figure 1.

Hierarchical clustering of differentially expressed genes in matched samples of transformed B-cell lymphomas before and after transformation to a high-grade non-Hodgkin's lymphoma (NHL). Four cases of follicular lymphoma (FL) (nos. 1-4) and one case of marginal zone lymphoma (no. 5) transformed to a high-grade NHL. Shown are the fold changes of all cases, calculated by two chip experiments per patient. Selection criteria were at least 3-fold changes in at least three of five transformations. The left column shows a cluster of genes with increased expression, and the right column shows a cluster of genes with decreased expression. Red $=$ increased expression; Blue $=$ decreased expression.

further immunohistochemistry was available for Cases 2,6 , and 7 .

\section{Confirmation of Microarray Data with QRT-PCR}

For all genes tested, we generated standard curves and graphs comparing the microarray data and QRTPCR. The RT-PCR analysis included two additional matched cases of FL transformation (nos. 6 and 7) for which not enough RNA was available for microarray studies, five unrelated FL, and five cases of de novo
DLBCL. The average correlation coefficient $\left(R^{2}\right)$ value for the standard curves for all genes tested was 0.994 \pm 0.02 (mean $\pm \mathrm{SD}$ ). The initial QRT-PCR confirmations were performed using TaqMan probes on 15 genes that were selected according to the following criteria: at least 3-fold increased or decreased gene expression in at least three of five cases with a minimal average difference value of one times the background value $(\sim 500)$ in either the low- or the high-grade samples. Because of the inclusion of genes with low average difference values, we expected a high percentage of false-positive microarray findings and confirmed 5 of 15 genes tested. Those genes were ABL2 (ARG), NEK2, HOXA1, and TPRC (PRCC) with increased expression, and PDCD1 with decreased expression; all had average difference values severalfold above the background value.

To improve the signal/noise ratio, a repeat data analysis was performed, increasing the average difference value requirements as described above to five times the background value (2500). The RT-PCR confirmation rate for genes selected according to these criteria was $78 \%$. Because of different program algorithms, Genespring-generated fold changes were usually higher than the Affymetrix calculations and the RT-PCR confirmation results. To compare these sets of data, we made a cutoff of at least 2-fold changes for Affymetrix software and QRT-PCR data. Figure 2 shows a good correlation of microarray and RT-PCR results for a representative gene, PDCD1. Table 5 lists all confirmed genes and shows the RT-PCR data for all seven matched samples, including two additional matched pairs that were used only for PCR analysis. In addition, the mean fold change comparing five unrelated FL with five de novo DLBCL is shown. Genes with a significance of $P<0.05$ using a two-tailed Student's $t$ test are indicated by asterisk. These results demonstrate a heterogenous pattern. Some genes are differentially expressed only in paired samples of FL/transformed DLBCL, whereas others are also found to be differentially expressed comparing unrelated cases of FL and de novo DLBCL.

\section{Extended Confirmation of Microarray Data with QRT-PCR Data in an Independent Case Series}

For further confirmation, we selected an unrelated series consisting of 5 normal lymph nodes, $15 \mathrm{FL}$ (3 FL grade 1, $6 \mathrm{FL}$ grade 2, $6 \mathrm{FL}$ grade 3), 12 DLBCL that transformed from a known low-grade lymphoma (5 from FL, 7 from other lymphomas including small lymphocytic lymphoma [SLL] and MALT), 24 de novo DLBCL, and lymphoma cell lines for comparison. Figure $3 \mathrm{~A}$ shows the expression data for ABL2. The higher expression of ABL2 in de novo DLBCL compared with $F L$ is statistically significant $(p=0.0038)$. In addition, ABL2 expression in FL grade 3 is higher than in grades 1 or 2, and the set of DLBCL that transformed from low-grade lymphomas contains a group of cases that have increased ABL2 expression when compared with FL grade 1. Figure 3B shows increasing NEK2 expression levels when comparing FL 
Table 2. Classification of differentially expressed genes in matched samples of transformed B-cell lymphomas before and after transformation to a high-grade NHL

\begin{tabular}{|c|c|c|c|c|}
\hline Cell/function & GB No. & & Gene expression & $P<0.05$ \\
\hline \multicolumn{5}{|l|}{ T cells } \\
\hline \multirow[t]{13}{*}{ Down } & X60992 & CD6 & & + \\
\hline & M37271 & $\mathrm{CD} 7$ & & + \\
\hline & U93049 & FYB & Fyn binding proteins & + \\
\hline & U26174 & GZMK & Granzyme K & + \\
\hline & D49394 & HTR3A & Serotonin receptor $3 \mathrm{~A}$, & \\
\hline & X76223 & MAL & T lymphocyte maturation-associated protein & + \\
\hline & X63380 & MEF2B & MADS box transcription enhancer factor & \\
\hline & D30755 & NAF1 & Nef-associated factor & + \\
\hline & L20971 & PDE4B & Phosphodiesterase 4B & + \\
\hline & U25956 & SELPLG & P-selectin glycoprotein ligand & + \\
\hline & U60800 & SEMA4D & CD100 & \\
\hline & X59871 & TCF7 & Transcription factor 7 & + \\
\hline & M12886 & TRB & $\mathrm{T}$ cell receptor beta locus & + \\
\hline \multicolumn{5}{|c|}{ Dendritic and stromal cells } \\
\hline Up & D56495 & REGL & Matrix protein & \\
\hline \multirow{4}{*}{ Down } & M26004 & CR2 & Complement component R2, CD21 & \\
\hline & M92934 & CTGF & Connective tissue growth factor & \\
\hline & X53331 & MGP & Matrix Gla protein & \\
\hline & U77180 & SCYA19 & MIP-3b, exodus-3 & + \\
\hline \multicolumn{5}{|l|}{ Transcription factors } \\
\hline \multirow[t]{3}{*}{ Up } & U52682 & IRF4 & MUM1 & \\
\hline & X79439 & NOTCH3 & Receptor & \\
\hline & M93650 & PAX6 & Transcription factor & \\
\hline \multirow[t]{7}{*}{ Down } & U15460 & B-ATF & Basic leucine zipper transcription factor & \\
\hline & $\mathrm{X} 62535$ & DGKA & Diacylglycerol kinase, alpha & + \\
\hline & M91196 & ICSBP1 & $\begin{array}{l}\text { Interferon consensus sequence binding } \\
\text { protein } 1\end{array}$ & \\
\hline & D45906 & LIMK2 & Lim domain kinase 2 & + \\
\hline & U27655 & RSG3 & Regulator of G-protein signaling 3 & \\
\hline & M97936 & STAT1 & $\begin{array}{l}\text { Signal transducer and activator of } \\
\text { transcription } 1\end{array}$ & \\
\hline & S73591 & VDUP1 & Induced by VitD3 & + \\
\hline \multicolumn{5}{|l|}{ Evading apoptosis } \\
\hline \multirow[t]{6}{*}{ Down } & X59350 & CD22 & BL-CAM & \\
\hline & M35878 & IGFBP3 & Insulin-like growth factor binding protein 3 & + \\
\hline & M33552 & LSP1 & Lymphocyte-specific protein & + \\
\hline & U64863 & PDCD-1 & Programmed cell death 1 & + \\
\hline & M98539 & PGD2S & Prostaglandin $\mathrm{D}_{2}$ synthase & + \\
\hline & M63928 & TNFRSF7 & $\mathrm{CD} 27$ & + \\
\hline \multicolumn{5}{|c|}{ Tissue invasion and metastasis } \\
\hline \multirow[t]{2}{*}{ Up } & D83542 & $\mathrm{CDH} 15$ & Cadherin $15, \mathrm{M}$ cadherin & \\
\hline & M32304 & TIMP & Tissue inhibitor of metalloproteinases & \\
\hline \multirow[t]{2}{*}{ Down } & X69819 & ICAM3 & Intercellular adhesion molecule 3 & + \\
\hline & J05070 & MMP9 & Matrix metalloproteinase 9 & + \\
\hline \multicolumn{5}{|c|}{ Proliferation and metabolism } \\
\hline \multirow[t]{11}{*}{ Up } & D13118 & ATP5G1 & ATP synthase & \\
\hline & X00351 & ACTB & Actin, beta & \\
\hline & D13627 & ССТ8 & Chaperonin-containing TCP1, subunit 8 & \\
\hline & L27943 & $\mathrm{CDA}$ & Cytidine deaminase & \\
\hline & U05340 & CDC20 & p55 & \\
\hline & Y08374 & CHI3L1 & Cartilage glycoprotein-39 & \\
\hline & M64108 & Col14A1 & Udulin1 & + \\
\hline & U50743 & FXYD2 & Na,K-ATPase gamma & \\
\hline & X01677 & GAPDH & Glyceraldehyde-3-phosphate dehydrogenase & \\
\hline & M90299 & GCK & Glucokinase & \\
\hline & J02621 & HMG14 & High-mobility group protein 14 & \\
\hline
\end{tabular}

Strict selection criteria were used. Genes with uniform changes resulting in a significance of $p<0.05$ are indicated. GB, GenBank accession number. 
Table 2. Continued

\begin{tabular}{|c|c|c|c|c|}
\hline Cell/function & GB No. & & Gene expression & $P<0.05$ \\
\hline \multicolumn{5}{|c|}{ Proliferation and metabolism } \\
\hline & X06985 & HMOX1 & Hemeoxygenase & \\
\hline & M34458 & LMNB & LaminB1 & \\
\hline & M21904 & MDU1 & CD98 heavy chain & \\
\hline & D49489 & P5 & Protein disulfide isomerase-related & \\
\hline & Z48501 & PABPC & Poly(A)-binding protein, cytoplasmic & \\
\hline & X94453 & PYCS & Pyrroline-5-carboxylate synthetase & + \\
\hline & M81758 & SCN4A & Na-channel & \\
\hline & Y10032 & SGK & Serum glucocorticoid regulated kinase & \\
\hline & J02683 & SLC25A & Solute carrier family 25 & \\
\hline & M34338 & SRM & Spermidine synthase & \\
\hline & $\mathrm{D} 21261$ & TAGLN2 & Transgelin 2 , actin crosslinking protein & \\
\hline & V00599 & TUBB & Tubulin, beta & \\
\hline & U73379 & UBCH10 & Ubiquitin carrier protein E2-C & \\
\hline \multirow[t]{4}{*}{ Down } & U37408 & CTBP1 & C-terminal binding protein 1 & \\
\hline & X04412 & GSN & Gelsolin, actin-depolymerizing factor & \\
\hline & D45248 & PSME2 & Proteasome activator subunit 2 & \\
\hline & X72889 & SMARCA & HBRM & \\
\hline \multicolumn{5}{|l|}{ Miscellaneous } \\
\hline \multirow[t]{6}{*}{ Up } & A28102 & GABAR $\alpha 3$ & Receptor & + \\
\hline & L32831 & GPR3 & G protein-coupled receptor 3 & \\
\hline & M32053 & $\mathrm{H} 19$ & Oncofetal RNA & \\
\hline & L41919 & HIC1 & Hypermethylated in cancer 1 & \\
\hline & U31342 & NUCB1 & Nucleobindin & \\
\hline & U49278 & UBE2V & Ubiquitin-conjugating enzyme E2 variant & \\
\hline \multirow[t]{33}{*}{ Down } & X57522 & ABCB2 & ATP-binding cassette subfamily B member 2 & \\
\hline & M34041 & ADRA2B & Adrenergic, alpha 2B receptor & \\
\hline & X05409 & ALDH2 & Aldehyde dehydrogenase, mitochondrial & \\
\hline & J03600 & Alox 5 & Arachidonate 5-lipoxygenase & \\
\hline & M63262 & AL0X5AP & 5-lipoxygenase activating protein & + \\
\hline & X68149 & BLR1 & Burkitt lymphoma receptor 1 , CXCR5 & \\
\hline & X78992 & BRF2 & Butyrate response factor 2 & \\
\hline & U97502 & ВT3.3 & Butyrophilin & \\
\hline & U90552 & BTN3A1 & Butyrophilin, subfamily 3 , member $A 1$ & \\
\hline & M59815 & C4A & Complement component C4A & + \\
\hline & J03507 & $\mathrm{C7}$ & Complement component 7 & + \\
\hline & L35594 & ENPP2 & ATX, autotaxin & + \\
\hline & M62831 & ETR101 & Immediate early protein & \\
\hline & Y12670 & HSOBRGRP & Leptin receptor gene-related protein & \\
\hline & U19247 & IFNGR $\alpha$ & Interferon gamma receptor alpha chain & + \\
\hline & L27560 & IGFBP5 & Insulin-like growth factor binding protein 5 & \\
\hline & L00022 & IGHE & Immunoglobulin heavy epsilon chain & \\
\hline & V00563 & IGHM & Immunoglobulin heavy constant mu & \\
\hline & X58529 & IGHM & Immunoglobulin heavy constant mu & \\
\hline & $X 57206$ & ITPKB & Inositol 1,4,5-triphosphate 3 kinase B & \\
\hline & U01062 & ITPR3 & Inositol 1,4,5-triphosphate receptor & \\
\hline & M87860 & LGALS2 & Human S-lac lectin L-14-II & + \\
\hline & U89922 & LTB & Lymphotoxin beta, TNFSF3 & + \\
\hline & U05572 & MAN2B1 & Mannosidase & \\
\hline & U51010 & NNMT & Nicotinamide-methyl transferase & \\
\hline & U08021 & NNMT & Nicotinamide-methyl transferase & \\
\hline & X97267 & PTPRCAP & LPAP, protein tyrosise phosphatase & \\
\hline & Z14982 & PSMB8 & Proteasome subunit, beta type 8 & \\
\hline & U08815 & SF3A3 & Splicing factor $3 a$, subunit 3 & + \\
\hline & U00968 & SREBF1 & Sterol regulatory element binding factor 1 & \\
\hline & X82240 & TCL1 & T-cell leukemia/lymphoma & \\
\hline & L40357 & TRIP 7 & Thyroid hormone interactor receptor 7 & \\
\hline & M63379 & TRPM-2 & Clusterin & + \\
\hline
\end{tabular}

Strict selection criteria were used. Genes with uniform changes resulting in a significance of $p<0.05$ are indicated. GB, GenBank accession number. 
Table 3. Correlation of immunohistochemistry and microarray gene expression data of serial samples of transformed B-cell lymphomas at the time of initial diagnosis and time of transformation

\begin{tabular}{|c|c|c|c|c|}
\hline \multirow{2}{*}{$\begin{array}{c}\mathrm{NHL} \\
\text { patient }\end{array}$} & \multirow[b]{2}{*}{ Gene } & \multicolumn{2}{|c|}{ Immunohistochemistry } & \multirow{2}{*}{$\frac{\text { Microarray gene expression }}{\text { Low- to high-grade comparison }}$} \\
\hline & & Low grade & High grade & \\
\hline \multirow[t]{7}{*}{ No. 1} & VEGF & + & ++ & 4-fold up \\
\hline & c-MYC & + & ++ & 14-fold up \\
\hline & CD20 & + & 0 & 11-fold down \\
\hline & CD22 & + & 0 & 6-fold down \\
\hline & BCL2 & ++ & + & 2-fold down \\
\hline & IRF4 & - & ++ & 8.5-fold up \\
\hline & Ki67 & ND & ++ & 4.3-fold up \\
\hline \multirow[t]{3}{*}{ No. 3} & IRF4 & - & + & 11.6-fold up \\
\hline & BCL2 & ++ & ++ & Expressed \\
\hline & CD20 & + & + & Expressed \\
\hline \multirow[t]{3}{*}{ No. 4} & IRF4 & - & - & 5.9-fold down \\
\hline & BCL2 & + & + & Expressed \\
\hline & CD20 & + & + & Expressed \\
\hline \multirow[t]{3}{*}{ No. 5} & IRF4 & - & - & 3.4-fold up \\
\hline & BCL2 & + & + & Expressed \\
\hline & CD20 & + & + & Expressed \\
\hline
\end{tabular}

The microarray results correlated well with protein expression data obtained at the time of either initial diagnosis or transformation. Because of limited amounts of available tissue, no material for further immunohistochemistry was available for case nos. 2, 6, and 7. VEGF, vascular endothelial growth factor; c-MYC, MYC proto-oncogene; CD20, B-lymphocyte surface antigen B1; CD22, B-cell membrane protein; BCL2, B-cell CLL/Lymphoma 2; Ki67, Proliferation marker; 0 = negative, $\pm=$ faint, $+=$ positive, $++=$ highly positive.

grades 1, 2, and 3 with transformed or de novo DLBCL. The higher expression of NEK2 in de novo DLBCL compared with FL is statistically significant ( $p$ $=0.0477)$. In addition, all DLBCL cell lines express NEK2 at high levels with only marginal expression in the follicular dendritic cell line HK. Figure 3C demonstrates statistically significant decreased expression levels of PDCD1 in transformed DLBCL $(p=0.0048)$ and de novo DLBCL $(p=0.0029)$ when compared with FL. All DLBCL cell lines expressed only minimal levels of PDCD1. The mantle cell lymphoma cell lines JEKO1 and NCEB expressed more PDCD1 than the DLBCL lines but at minimal levels when compared with the patient lymphoma samples. Figure 3D shows the expression of VDUP1. Although the expression levels were not different comparing FL with de novo DLBCL, a difference between $\mathrm{FL}$ and transformed DLBCL was observed that just missed the level of statistical significance $(p=0.0708)$. Again, the DLBCL cell lines showed only very low VDUP1 expression.

\section{Immunohistochemical Confirmation of Microarray Data in an Independent Case Series}

For further confirmation, we selected an unrelated series of $50 \mathrm{NHL}$ including $16 \mathrm{FL}$ grades 1 to 3,13 DLBCL that transformed from low-grade lymphomas (6 from FL, 7 from other low grade lymphomas), and 21 de novo DLBCL. Frozen sections were stained with antibody specific for interferon regulatory factor 4/multiple myeloma oncogene 1 (IRF4/MUM1) (Table 6). Only $6 \%$ of FL (one individual) expressed IRF4/ MUM. This case was a grade $3 \mathrm{FL}$ with $2+$ staining in $70 \%$ of cells. In marked contrast, $81 \%$ of de novo DLBCL (17 of 21) expressed IRF4/MUM1, as did 69\% of DLBCL that transformed from preexisting lowgrade lymphomas (9 of 13). Within this latter group, IRF4/MUM1 was expressed in $83 \%$ of DLBCL that transformed from FL (5 of 6 ) and in $57 \%$ of DLBCL (4 of 7) that transformed from other low-grade lymphomas (MALT, SLL). In most cases, staining was of 2 to $3+$ intensity in more than $20 \%$ of neoplastic cells. Representative staining for IRF4/MUM1 is illustrated in Figure 3.

\section{Discussion}

The process of transformation of low-grade to highgrade NHL is not well characterized, and new approaches to elucidate the underlying mechanisms are needed. We were able to obtain seven matched samples of NHL from the same patients before and after transformation. All but one of the cases were FL grade I that transformed to a high-grade NHL. One case was a marginal zone lymphoma that transformed to a DLBCL. With gene expression profiling of these matched samples and QRT-PCR in an extended series of lymphomas, we identified and validated highly differentially expressed genes, generating new hypotheses of the underlying transforming events.

The transformation of FL is a heterogenous process. Uniform gene expression changes seen in all transformations are therefore not expected. To identify changes that might occur in a subgroup, we selected genes that were altered in at least three of five paired samples for which microarray data were available. The genes were selected according to very strict criteria to keep the validation rate using QRT-PCR as high as possible. Those genes were then grouped according to their known function. Studies analyzing the core 
A

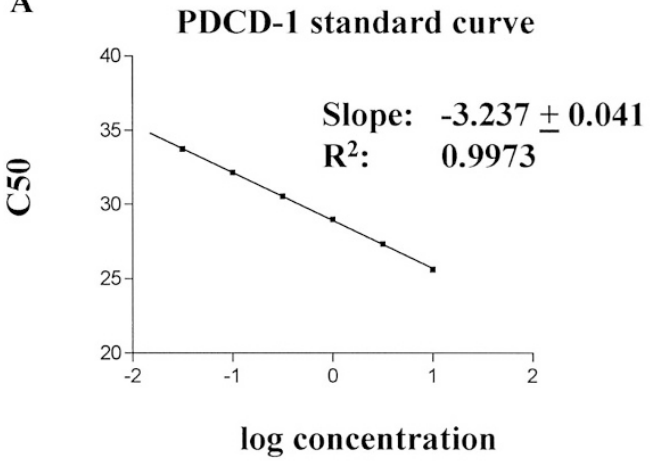

B

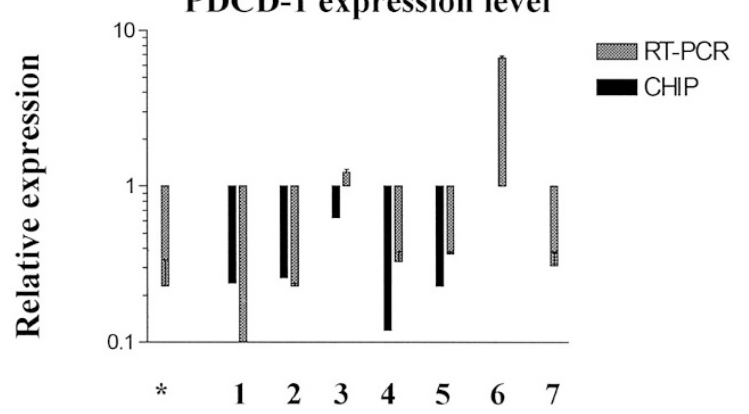

Figure 2.

Quantitative real-time PCR (QRT-PCR) of PDCD1. This figure shows the standard curve and the correlation of PCR and microarray data of PDCD1 as a representative sample. A, Standard curve: the standard curves were generated by serial dilutions of $100 \mathrm{ng} / \mu \mathrm{l} \mathrm{cDNA}$ samples in five $\div 10$-fold dilution steps and used for regression analyses. B, Correlation of microarray data and QRT-PCR. The comparison of five different FL compared with five unrelated de novo diffuse large B-cell lymphoma (DLBCL) is indicated by the asterisk. Cases 1 to 5 are the paired samples of transformed B-cell lymphoma for which microarray data are available. Numbers 6 to 7 are additional paired samples of transformed B-cell lymphoma for which microarray data were not available because of limited amounts of RNA.

meiotic transcriptome in budding yeast have demonstrated that only $10 \%$ of specifically regulated genes during meiosis were in fact essential for that process (Kaback and Feldberg, 1985; Primig et al, 2000). Extrapolation of those findings led us to assume that the percentage of functionally essential genes among the group of differentially expressed genes in FL transformation might be rather low. We attempted to increase the odds of finding functionally relevant candidate genes by concentrating on genes that were not related to contaminating $\mathrm{T}$ or dendritic cells and whose known functions implied a possible pathogenic role. We found genes with decreased expression that reflect the presence of contaminating germinal center type $T$ cells and follicular dendritic cells in the lowgrade lymphoma samples compared with the DLBCL. In addition, a cluster of genes associated with cell growth and metabolism reflected the different growth rates between low- and high-grade lymphomas. Most of these genes were thought to be of less interest as they appeared unrelated to the transforming events. But we are aware that "contaminating" stromal cells may have a contributing role in the growth of lymphoma cells, such as producing proteins that remodel the extracellular matrix (Alizadeh et al, 2000).
For validation, we compared protein expression data obtained routinely at times of diagnosis and progression with the microarray gene expression data and found a very good correlation. Our confirmation rate of selected genes using QRT-PCR (78\%) compares favorably with a published confirmation rate of $71 \%$ (Rajeevan et al, 2001). Several genes that we found to be increased have already been published as markers for transformed/aggressive lymphoma, providing independent validation of our data and our search strategy. These genes include nucleobindin (Kubota et al, 1998), IRF4 (Falini et al, 2000; lida et al, 1997; Tsuboi et al, 2000), and tissue inhibitor of metalloproteinases (Kossakowska et al, 1993, 1999). Nucleobindin has DNA-binding ability (Miura et al, 1992) and may play a role in $G$ protein-regulated and $\mathrm{Ca}^{+}{ }^{-}$-regulated signal transduction (Lin et al, 2000). IRF4, also known as MUM1, is involved in the chromosomal translocation $\mathrm{t}(6 ; 14)$ that occurs in multiple myeloma, and it has been found to have oncogenic activity in vitro (lida et al, 1997). Expression of tissue inhibitor of metalloproteinases is associated with a poor clinical outcome in NHL (Kossakowska et al, 1993, 1999). In the case of IRF4/MUM1, we confirmed expression of the protein by immunohistochemistry in an unrelated series of 50 lymphomas. Only 1 of $16 \mathrm{FL}$ expressed IRF4/MUM1 (a case of FL grade 3), whereas $69 \%$ of transformed DLBCL and $81 \%$ of de novo DLBCL prominently expressed the protein.

While this manuscript was under review, Lossos et al (2002) published their series of FL that transformed to DLBCL. Neither we nor Lossos et al found uniformly differentially expressed genes throughout all paired patient samples. In their series, consistent changes were observed only in up to 4 of 12 paired cases. Instead, a marked heterogeneity was observed, with consistent expression changes occurring only in a subset of transformed DLBCL. These findings are consistent with a multistep transformation process involving many alternative pathways in transformed DLBCL. Some genes are differentially expressed only in paired samples of FL/transformed DLBCL, whereas others are also found to be differentially expressed comparing unrelated cases of FL and de novo DLBCL.

Figure 4 lists selected, confirmed, differentially expressed genes in transformed FL in the context of their likely functional contribution to the transformation step. Genes that provide growth stimulation, potentially decrease apoptotic cell death, or lessen cell adhesion are shown. New hypothetical pathogenic mechanisms of FL transformation are represented by the following selected candidate genes that we found to be differentially expressed in transformed lymphomas.

$A R G$, also known as $A B L 2$, is an $A B L-r e l a t e d$ gene with a structure similar to the Abelson gene (ABL) (Kruh et al, 1986). It is highly related to $A B L$ at its $\mathrm{SH} 3$, $\mathrm{SH} 2$, and kinase domains but is only $30 \%$ similar at the C-terminal level (Kruh et al, 1990). The function of $A R G$ is not well understood. However, in a recently reported $t(1 ; 12)(q 25, p 13)$ translocation in a patient with acute leukemia, ARG was fused to the TEL gene 
Table 4a. Primers and probes used for quantitative RT-PCR

\begin{tabular}{llll}
\hline \multicolumn{1}{c}{ Gene } & \multicolumn{1}{c}{ 5' $^{\prime}$ Primer } & \multicolumn{1}{c}{ 3' $^{\prime}$ Primer } & Probe $\left(5^{\prime}-\right.$ FAM $-3^{\prime}$ TAMRA $)$ \\
\hline ABL2 & AGCATGCTGATGGGTTCTCT & AGGTTCCTCTGTGCAAAGCT & CTCCTGCCCAGCAAGAGGCG \\
HOXA1 & AGTACGGCTACCTGGGTCAA & CGCGTCAGGTACTTGTTGAA & AACGCGGTGCGCACCAACTT \\
NEK2 & GAAGAGGGCGACAATTAGGA & CTCGCTCTCGCTCCTGTAAC & CGCAGGATTCCAGCCCTGTATTGA \\
PDCD-1 & GCTAAACTGGTACCGCATGAG & CAGTTGTGTGACACGGAAGC & ACGGACAAGCTGGCCGCCTT \\
TPRC & ATGCCGCTGGTGCTTATTAT & ATCGATGAAGGAGGCATCTG & ATCCTGCACAGGACCCGGCC \\
\hline
\end{tabular}

Primer probes were designed using the PRIMER3 software (http://www.genome.wi.mit.edu/cgi-bin/primer3_www.cgi) using sequence data from the NCB database. Shown are the primers and probes of confirmed genes.

Table 4b. Primers and melting points (MP) for quantitative SYBRGreen RT-PCR

\begin{tabular}{|c|c|c|c|}
\hline Gene & 5' Primer & 3' Primer & MP \\
\hline B-ATF & AGCGAAGACCTGGAGAAACA & TTCAGCACCGACGTGAAGTA & 83.5 \\
\hline CD22 & TGACCTGGAAAGCTTCATCC & GGAACCTTCCCATCCTTTGT & 80.5 \\
\hline CD27 & CATCACTGCCAATGCTGAGT & GGGTTTGGAAGAGGATCACA & 85.5 \\
\hline CDC20 & AAGACCTGCCGTTACATTCC & TTCCCAGAACTCCAATCCAC & 83 \\
\hline $\mathrm{CR} 2$ & ATCCTAAGAGGCCGAATGGT & CCTTCAAGGTGAAGCCAAAC & 79.5 \\
\hline ETR101 & GAAGTGCAGAAAGAGGCACA & TGCGGGAGTGATACATCTTC & 83.5 \\
\hline ICAM3 & GTGTTTGAAGGAAGGCTCCA & TGTATTTGCCTCGTGAGCTG & 85 \\
\hline IGFBP3 & TGGTAGTTGTGCAGCATCGT & ATCAGGAAGGACCAGAGCAA & 79 \\
\hline IGHM & CACCAAGTCCACCAAGTTGA & GGTGTGGGTTTTCACAGCTT & 86 \\
\hline ICSBP1 & CCAGGACTGATTTGGGAGAA & AATGGAGGCATCCACTTCCT & 82 \\
\hline IRF4 & AGAAGAGCATCTTCCGCATC & CCTTTAAACAGTGCCCAAGC & 87.5 \\
\hline ITPK3 & AGGCCATTCGAACCACTCTA & TTGGCCTGTTCCTTCTTGTC & 83 \\
\hline NBK & TGTATGAGCAGCTCCTGGAA & AGTCATGCCAAGAACCTCCA & 80 \\
\hline NOTCH3 & CAGCCTCATGGCAGAATAGA & TGCAGCTTCTCCAACACATC & 78.5 \\
\hline NUCB1 & GTGACCAGAAGGAGGTGGAC & GGTCCGAGATCACAGATGCT & 84 \\
\hline PDCD-1 & TGCAGCTTCTCCAACACATC & CATGCGGTACCAGTTTAGCA & 79.5 \\
\hline RGP3 & CAGTGTTCCAAGCCTTCCTT & CTTGGATGCCATCTTGGACT & 83.5 \\
\hline TCF-1 & GCAACCTGAAGACACAAGCA & GCAATGACCTTGGCTCTCAT & 84 \\
\hline TRPM2 & GGTCTGGCACCCAAAGATAA & GACAAGCCTTGCTCTGGAAA & 80 \\
\hline VDUP1 & AGCCTTCGGGTTCAGAAGAT & TTGGATCCAGGAACGCTAAC & 83.5 \\
\hline
\end{tabular}

Primer probes were designed using the PRIMER3 software (http://www.genome.wi.mit.edu/cgi-bin/primer3_www.cgi) using sequence data from the NCBI database. Shown are the primers and probes of confirmed genes. MP in degrees Celsius.

(Cazzaniga et al, 1999; lijima et al, 2000). This fusion probably increased the tyrosine kinase activity of ARG. In vitro studies showed that the ARG kinase can be inhibited by STI571 (Okuda et al, 2001). The gene expression level of ARG was increased in our transformed FL samples. We speculate that the ARG gene might be involved in activating translocations in transformed FL.

NEK2 is a serine/threonine-protein kinase that is involved in mitotic regulation. It has been found to be a core component of the centrosome and, upon overexpression, NEK2 can stimulate centrosome splitting (Fry et al, 1998). During development, this protein accumulates throughout $S$ phase and shows maximal levels in late G2. This expression pattern is highly reminiscent of that of $A$ and $B$ cyclins (Fry et al, 1995). NEK2 is a member of the NIMA-related kinase family. NIMA was first identified in the filamentous fungus Aspergillus nidulans as a protein whose kinase activity is essential for mitotic entry (Fry et al, 1995). Temperature-sensitive nimA mutants arrest in G2 at the restrictive temperature, whereas overexpression of NIMA leads to a rapid entry into mitosis from any point in the cell cycle (Fry, 2002). The first report that NEK2 expression is increased in certain tumor cells has come from microarray studies of Ewing tumorderived cell lines (Wai et al, 2002). Here, we report that NEK2 is overexpressed in transformed and de novo DLBCL. To our knowledge, this is the first report of high levels of NEK2 in primary human tumors.

We have found that programmed cell death 1 (PDCD1) is decreased in transformed and de novo DLBCL. It is an Ig superfamily member, containing an immunoreceptor inhibitory motif in the cytoplasmic tail and is thought to be involved in the negative regulation of B-cell proliferation and differentiation (Freeman et al, 2000). PDCD1 is activated in lymphatic cell lines undergoing programmed cell death (Ishida et al, 1992), suggesting a role of this protein in apoptosis. When PDCD1 is disrupted, mice develop a lupus-like disease (Nishimura et al, 1999) or an autoimmune dilated cardiomyopathy (Nishimura et al, 2001). We have found this gene to be very poorly expressed in MCL (Hofmann et al, 2001), and we propose that the low expression of PDCD1 may contribute to the accumulation of abnormal B cells in NHL. 


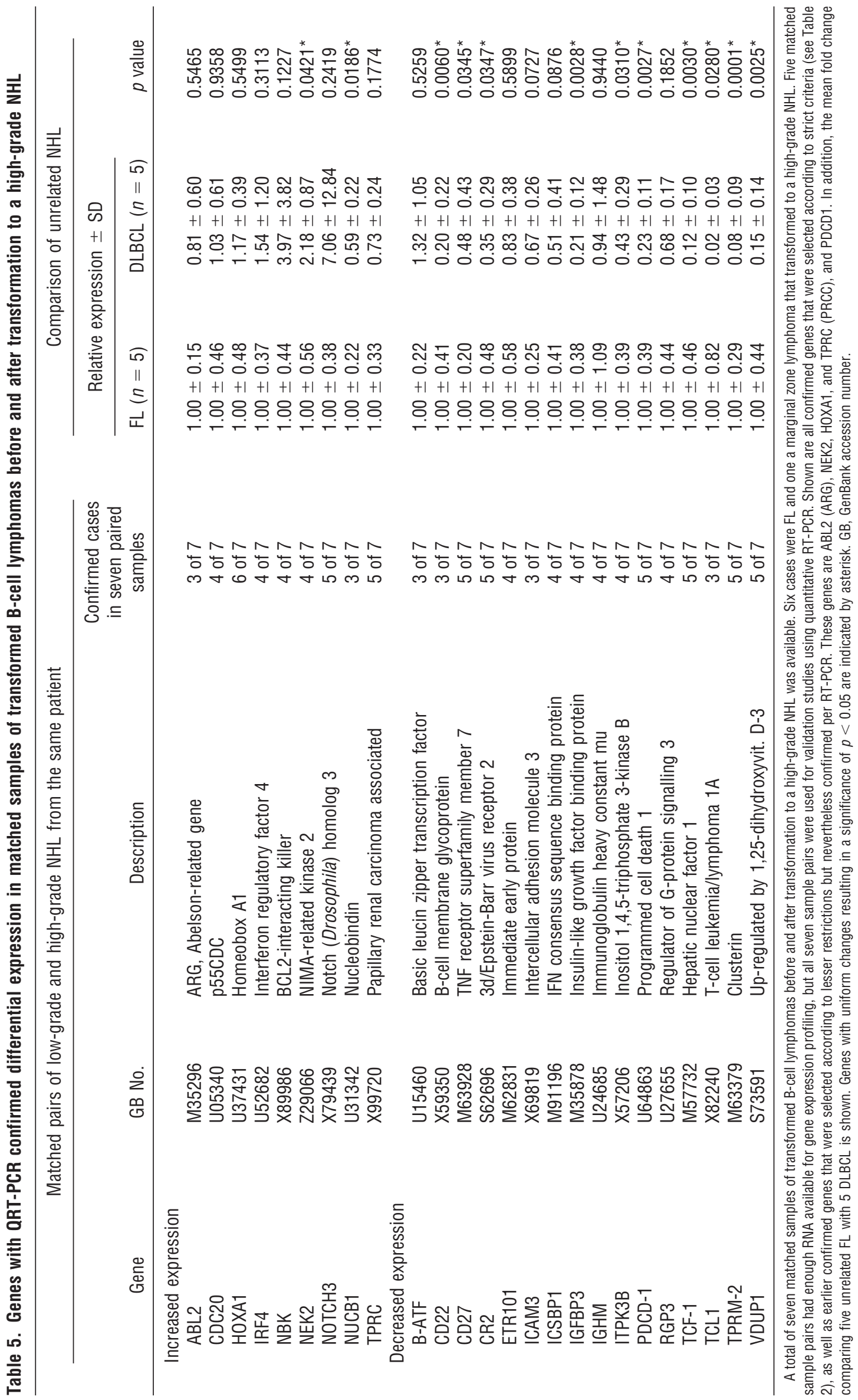



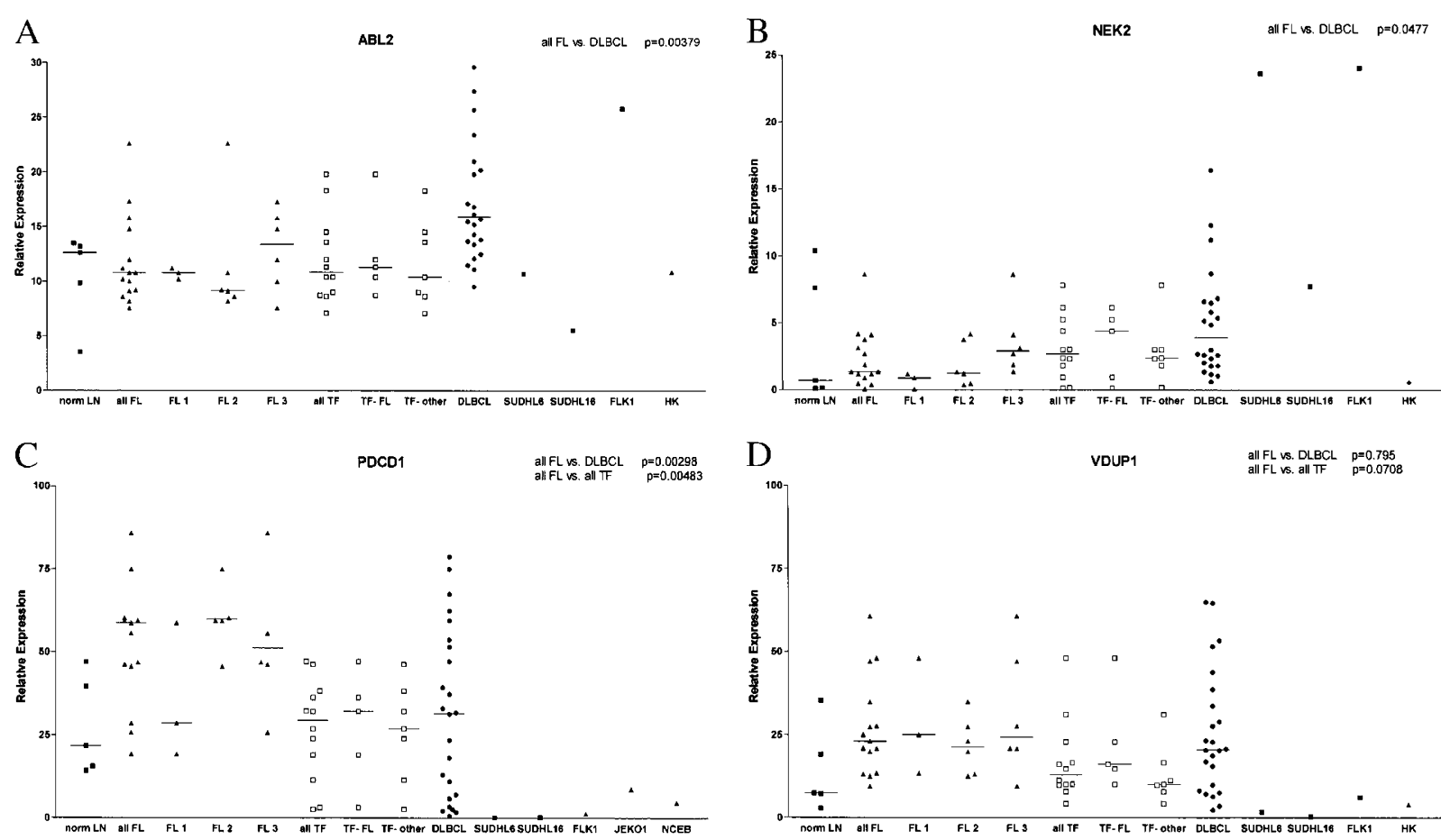

Figure 3.

QRT-PCR in an unrelated series of lymphomas including 5 normal lymph nodes, $15 \mathrm{FL}$ ( $3 \mathrm{FL}$ grade 1, $6 \mathrm{FL}$ grade 2, and $6 \mathrm{FL}$ grade 3 ), 12 DLBCL that transformed from a known low-grade lymphoma (5 from FL, 7 from other lymphomas including SLL and MALT), 24 de novo DLBCL, and lymphoma cell lines for comparison were selected. Shown are the expression data for (A) ABL2, (B) NEK2, (C) PDCD1, and (D) VDUP1. The $p$ values comparing different lymphoma subtypes are shown.

Table 6. Confirmation of microarray data with immunohistochemistry for IRF4/MUM1 in an independent case series

\begin{tabular}{|c|c|c|c|}
\hline \multirow[b]{2}{*}{ Histology } & \multirow[b]{2}{*}{$\mathrm{n}$} & \multicolumn{2}{|c|}{$\begin{array}{l}\text { IRF4/ } \\
\text { MUM1 } \\
\text { positive }\end{array}$} \\
\hline & & $\mathrm{n}$ & $\%$ \\
\hline \multicolumn{4}{|l|}{$\mathrm{FL}$} \\
\hline Grade I & 3 & 0 & 0 \\
\hline Grade II & 6 & 0 & 0 \\
\hline Grade III & 7 & 1 & 14 \\
\hline Total & 16 & 1 & 6 \\
\hline \multicolumn{4}{|l|}{ DLBCL (transformed) } \\
\hline Prior FL & 6 & 5 & 83 \\
\hline Prior other low-grade lymphoma & 7 & 4 & 57 \\
\hline Total & 13 & 9 & 69 \\
\hline DLBCL (de novo) & 21 & 17 & 81 \\
\hline
\end{tabular}

Confirmation of the microarray data used immunohistochemistry in an independent case series of $50 \mathrm{NHL}$ cases, including $16 \mathrm{FL}$ grades $1-3,13$ DLBCL that transformed from a low-grade lymphoma (6 from FL, 7 from other low-grade lymphomas), and 21 de novo DLBCL. Frozen sections were stained with an antibody against IRF4/MUM1.

We found VDUP1 expression to be decreased in transformed DLBCL and in a subset of de novo DLBCL. Vitamin $\mathrm{D}_{3}$ up-regulated protein 1 (VDUP1)/ thioredoxin-binding protein-2 (TBP-2) has been previously isolated and characterized as a gene upregulated by 1,25-dihydroxyvitamin D3 in HL-60 cells (Chen and DeLuca, 1994). It has also been shown that VDUP1 is a cytoplasmic protein that binds to and inhibits active (reduced) thioredoxin (TRX), with amino acids 155 to 225 required for binding (Junn et al, 2000). VDUP1 has been implicated as a redoxsensitive tumor suppressor. By inhibiting the function of TRX, VDUP1 plays a role in cell proliferation and oxidative stress by influencing the redox state of the cell (Nishiyama et al, 1999). TRX has been shown to modulate DNA-binding activity of several transcription factors, such as TFIIIC, BZLF1, nuclear factor- $\kappa B$, Ref-1, and p53, while inducing AP-1 through de novo transcription of c-jun and c-fos (Toledano and Leonard, 1991). Although VDUP1 is suppressed in HTLV-I transformed T-cell lines, overexpression of VDUP1 suppresses their cell growth, indicating its possible involvement in tumorigenesis (Masutani and Yodoi, 2002). In addition, it has been shown that the histone deacetylase inhibitor SAHA arrests cancer cell growth, up-regulates VDUP1, and down-regulates TRX in prostate and bladder cancer cell lines (Butler et al, 2002). Further, VDUP1 mRNA levels were found to be reduced in human breast and colon tumor tissue compared with matched samples of normal tissues (Butler et al, 2002). To our knowledge, this is the first report describing differential VDUP1 expression in FL and DLBCL.

In summary, we have identified and validated differentially expressed genes in transformed FL, including already known markers of high-grade NHL, but also new candidate genes including ABL2, NEK2, PDCD1, and VDUP1. The transformation of FL to DLBCL is a heterogenous process, and confirmed gene alterations in a subset of investigated cases might be 


\section{IRF4/MUM1 expression}

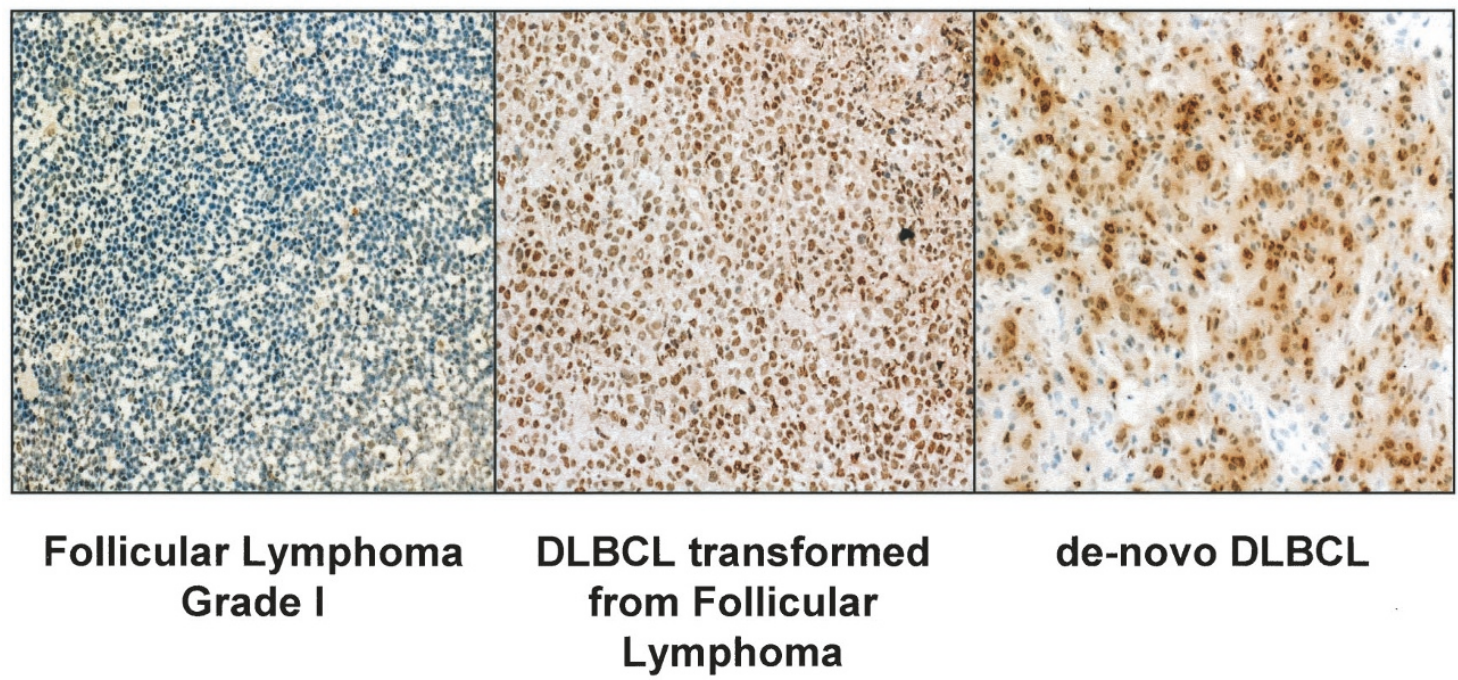

Figure 4.

Representative, confirmatory immunohistochemistry for interferon regulatory factor 4/multiple myeloma oncogene 1 (IRF4/MUM1) was performed in an unrelated series of 50 lymphomas, including FL, transformed B-cell lymphomas, and de novo DLBCLs. Shown is a characteristic pattern of staining in a grade $1 \mathrm{FL}$, de novo and transformed DLBCL.

significant, generating new hypotheses about deregulated pathways (Figure 5).

\section{Materials and Methods}

\section{Patients}

Seven pairs of snap-frozen lymph nodes, derived from patients who transformed from low- to high-grade B-cell lymphoma were obtained largely from the central lymphoma repository of the Southwest Oncology

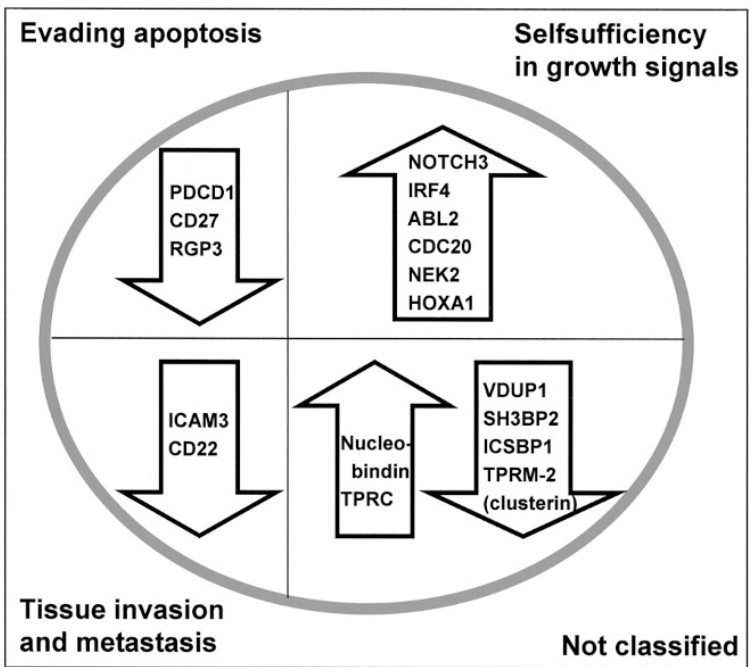

Figure 5.

Confirmed differentially expressed genes in transformed B-cell lymphoma. The change of gene expression is indicated by up/down arrows. The candidate genes are classified according to the likely functional consequences of their changed expression for lymphoma progression.
Group lymphoma collection. The lymphomas were classified according to the World Health Organization classification scheme (Jaffe et al, 2001). Five cases (nos. 2, 3, 4, 6, and 7) were FL grade I that transformed to DLBCL; one FL grade I transformed to a Burkitt-like lymphoma (no. 1), and one marginal zone lymphoma transformed to a DLBCL (no. 5). The successive transformation of the original low-grade lymphoma clone was evidenced by identical light chain restrictions of the low- and high-grade lymphomas in five of the seven matched patient samples where data were available. Additional unrelated cases of five FL and five de novo DLBCL were used for QRT-PCR studies in each of the studied candidate genes. For further confirmation, a larger series of 50 unrelated cases including $16 \mathrm{FL}$ grades 1 to $3,13 \mathrm{DLBCL}$ that transformed from low-grade lymphomas (6 transformed from FL, 7 from other low-grade lymphomas), and 21 de novo DLBCL were selected for immunohistochemistry studies. Five normal lymph nodes, $15 \mathrm{FL}$ (3 grade 1, 6 grade 2, 6 grade 3), 12 DLBCL that transformed from a known low-grade lymphoma ( 5 from FL, 7 from other lymphomas including SLL, and MALT), 24 de novo DLBCL, and lymphoma cell lines were used for QRT-PCR confirmation studies. The SUDHL-6, SUDHL-16, and FLK1 cell lines are derived from patients with DLBCL harboring the $t(14 ; 18)$ translocation. HK is a follicular dendritic cell line; JEKO1 and NCEB are mantle cell lymphoma cell lines.

\section{RNA Extraction}

Frozen sections (30 serial $20-\mu \mathrm{m}$ sections) were collected for RNA extraction. The areas selected were uniformly either low- or high-grade NHL, without visi- 
ble significant contamination with other tissues in hematoxylin and eosin (HE) stains and were microdissected when necessary. Total RNA was extracted using STAT-60 (Tell-Test, Inc., Friendswood, Texas), followed by a purification step using the RNeasy cleanup kit (QIAGEN, Inc., Valencia, California), according to the manufacturer's protocol. The RNA quality was confirmed on an agarose gel.

\section{Oligonucleotide Microarrays}

The HuGeneFL Array (Affymetrix Inc., Santa Clara, California) provides gene expression data for 5600 full-length human sequences. Each set of matched samples was studied with two microarrays. The preparation and microarray processing was performed per standard Affymetrix protocol as previously published (Hofmann et al, 2001). The raw data image was analyzed using the GeneChip Analysis Suite (Affymetrix Inc.), and the data for each microarray were normalized by global scaling to a target value of 2500 . The average background noise was in the range of 500. For quality control purposes, we evaluated the percentage of "present" calls per chip; the cutoff was set at $20 \%$. Using the housekeeping genes $\beta$-actin and glyceraldehyde-3-phosphate dehydrogenase, we evaluated the ratio of average difference values of the 3 ' versus 5' mRNA expression; sufficient RNA integrity was assumed if that ratio was $\leq 2.0$.

\section{Data Analysis}

We performed a supervised data analysis with matched paired samples of transformed low-grade lymphoma. For five of the paired samples, enough RNA was available to perform microarray analyses (Samples 1 to 5). Because of a limited case series and the high likelihood of nonuniform transforming events, we chose to search for highly differentially expressed genes in at least three of our five cases. In addition, we selected genes with sufficiently high average difference values to increase our confirmation rate with secondary techniques. The raw data values were required to be 5-fold higher than the background level of 500, and the fold changes were at least 3-fold. We used the GeneChip analysis suite for pairwise comparisons and the Genespring software (Silicon Genetics, Inc., Redwood City, California) for clustering, statistical analysis, and visualization. The value of statistical analyses was limited because of the low case numbers and resulted in statistical significance in only those situations in which the changes were uniform within the whole study set. The $p$ values for the microarray data of differentially expressed genes were generated for the five paired samples using a paired $t$ test, with a significance level $\alpha$ at 0.05 . However, highly differentially expressed genes in a subset of cases might still be meaningful and were therefore included in further confirmation studies. For hierarchical clustering of genes and patient samples, we used the Pearson correlation algorithm.

\section{QRT-PCR}

After DNase treatment with RQ1 DNAsel (Promega, Madison, Wisconsin), $2 \mu \mathrm{g}$ of total RNA was reverse transcribed using Superscript II (Life Technologies, Grand Island, New York) according to the manufacturer's protocol in a total volume of $50 \mu$ l. Quantitative PCR was performed using either TaqMan probes or SYBRGreen for the detection of fluorescence during amplification. The initial RT-PCR confirmations were performed using TaqMan probes. All PCR primers (Life Technologies) and TaqMan probes (Applied Biosystems, Foster City, California) were designed using the PRIMER3 software (http://www.genome.wi.mit.edu/cgi-bin/ primer/primer3_www.cgi) and sequence data from the NCBI database (Table 4, a and b). The primer Tm was $58^{\circ} \mathrm{C}$ to $60^{\circ} \mathrm{C}$. The TaqMan probes were labeled with the reporter dye 6-carboxyfluorescein in the 5 'end and the quencher dye 6-carboxy-tetramethyl-rhodamine in the 3'end. For TaqMan probes, each amplification reaction contained $5 \mu$ l of a 1:10 dilution of the original cDNA, $12.5 \mu \mathrm{l}$ of the Universal TaqMan $2 \times$ PCR mastermix (Applied Biosystems), and specific primers in $300 \mathrm{~nm}$ and the probe in $100 \mathrm{~nm}$ concentration in a final volume of 25 $\mu$ l. All reactions were performed in triplicates in an iCycler iQ system (BioRad, Hercules, California), and the thermal cycling conditions were 2 minutes at $50^{\circ} \mathrm{C}, 10$ minutes at $95^{\circ} \mathrm{C}$, followed by 45 cycles of $95^{\circ} \mathrm{C}$ for 15 seconds and $60^{\circ} \mathrm{C}$ for 1 minute. Normalization was performed using the expression of 18S rDNA as an internal control. $\beta$-actin is located on chromosome 7 , which is often aberrant in lymphomas (Johansson et al, 1995). It was shown to be up-regulated in the majority of our transformed lymphoma samples and was therefore unsuitable for normalization purposes.

For economy, we used SYBRGreen detection for selected genes. A 25- $\mu$ l RT-PCR reaction consisted of $2.5 \mu \mathrm{l}$ of $10 \times$ HotStarTaq PCR buffer, $10 \mathrm{~mm}$ of each dNTP, 10 pmol of each primer, $0.25 \mu$ of SYBRGreen (Molecular Probes, Eugene, Oregon) in a 1:600 dilution in $1 \%$ dimethyl sulfoxide, $0.625 U$ of HotStarTaq (Qiagen, Valencia, CA), and 50 ng cDNA, or 1 pg of cDNA when measuring 18S. In initial experiments, gene fragments were amplified using PCR conditions as follows: $95^{\circ} \mathrm{C}$ for 15 minutes, followed by 45 cycles of $95^{\circ} \mathrm{C}$ for 15 seconds, $60^{\circ} \mathrm{C}$ for 15 seconds, $72^{\circ} \mathrm{C}$ for 30 seconds. Melting temperatures of these fragments were determined according to the manufacturer's protocol. The thermal cycling conditions for SYBRGreen RT-PCR were $95^{\circ} \mathrm{C}$ for 15 minutes, followed by 45 cycles of $95^{\circ} \mathrm{C}$ for 15 seconds, $60^{\circ} \mathrm{C}$ for 15 seconds, $72^{\circ} \mathrm{C}$ for 30 seconds, and the specific melting temperature for 20 seconds. The standard curves were generated by serial dilutions of $100 \mathrm{ng} / \mu \mathrm{l}$ sample cDNA in five $\div 10$-fold dilution steps and used for regression analyses. SYBRGreen QRT-PCR gave identical results to the TaqMan RT-PCR as tested on a limited set of genes (data not shown). The variance of the triplicate measurements was $<5 \%$ for both TaqMan and SYBRGreen RT-PCR. When correlating fold changes, the Genespring generated values were usually higher than the GeneChip calculations and the 
RT-PCR confirmation results. The cutoff was set to at least 2-fold changes when correlating microarray data (GeneChip software) and QRT-PCR data. The $p$ values for the QRT-PCR data of the unrelated NHL series were generated using a two-tailed Student's $t$ test, assuming equal variance, with a significance level $\alpha$ at 0.05 .

\section{Immunohistochemistry}

Immunohistochemistry was performed as previously described (Grogan et al, 1995). Briefly, we used snapfrozen sections fixed in $4^{\circ} \mathrm{C} 100 \%$ acetone and applied the relevant antibodies using standard immunoperoxidase techniques in an automated immunostainer "VMS 320" (Ventana Medical Systems, Tucson, Arizona) or a Dako autostainer (Carpenteria, California).

Immunohistochemistry staining was graded by two observers according to the intensity of the stain (1 to $3+$ ) as well as the percentage of positive cells. To be considered IRF4/MUM1 positive, we required at least $1+$ staining intensity in $>10 \%$ of cells.

\section{Acknowledgements}

We thank Drs. Peter Rosen and Fred Rosenfelt for helpful discussions.

\section{References}

Alizadeh AA, Eisen MB, Davis RE, Ma C, Lossos IS, Rosenwald A, Boldrick JC, Sabet H, Tran T, Yu X, Powell JI, Yang L, Marti GE, Moore T, Hudson J Jr, Lu L, Lewis DB, Tibshirani R, Sherlock G, Chan WC, Greiner TC, Weisenburger DD, Armitage JO, Warnke R, Staudt LM, et al (2000). Distinct types of diffuse large B-cell lymphoma identified by gene expression profiling. Nature 403:503-511.

Aventin A, Mecucci C, Guanyabens C, Brunet S, Soler J, Bordes R, and Hvan den Berghe (1990). Variant $t(2 ; 18)$ translocation in a Burkitt conversion of follicular lymphoma. $\mathrm{Br} J$ Haematol 74:367-369.

Bastion Y, Sebban C, Berger F, Felman P, Salles G, Dumontet C, Bryon PA, and Coiffier B (1997). Incidence, predictive factors, and outcome of lymphoma transformation in follicular lymphoma patients. J Clin Oncol 15:1587-1594.

Bentz M, Werner CA, Dohner H, Joos S, Barth TF, Siebert R, Schroder M, Stilgenbauer S, Fischer K, Moller P, and Lichter $P$ (1996). High incidence of chromosomal imbalances and gene amplifications in the classical follicular variant of follicle center lymphoma. Blood 88:1437-1444.

Butler LM, Zhou X, Xu WS, Scher HI, Rifkind RA, Marks PA, and Richon VM (2002). The histone deacetylase inhibitor SAHA arrests cancer cell growth, up-regulates thioredoxinbinding protein-2, and down-regulates thioredoxin. Proc Natl Acad Sci USA 99:11700-11705.

Cazzaniga G, Tosi S, Aloisi A, Giudici G, Daniotti M, Pioltelli $P$, Kearney L, and Biondi A (1999). The tyrosine kinase abl-related gene ARG is fused to ETV6 in an AML-M4Eo patient with a $\mathrm{t}(1 ; 12)(\mathrm{q} 25 ; \mathrm{p} 13)$ : Molecular cloning of both reciprocal transcripts. Blood 94:4370-4373.

Chen KS and DeLuca HF (1994). Isolation and characterization of a novel cDNA from HL-60 cells treated with 1,25dihydroxyvitamin D-3. Biochim Biophys Acta 1219:26-32.
Come SE, Jaffe ES, Andersen JC, Mann RB, Johnson BL, DeVita VT Jr, and Young RC (1980). Non-Hodgkin's lymphomas in leukemic phase: Clinicopathologic correlations. Am J Med 69:667-674.

De Jong D, Voetdijk BM, Beverstock GC, van Ommen GJ, Willemze R, and Kluin PM (1988). Activation of the c-myc oncogene in a precursor-B-cell blast crisis of follicular lymphoma, presenting as composite lymphoma. $\mathrm{N}$ Engl $\mathrm{J}$ Med 318:1373-1378.

Elenitoba-Johnson KS, Gascoyne RD, Lim MS, Chhanabai M, Jaffe ES, and Raffeld M (1998). Homozygous deletions at chromosome 9p21 involving p16 and p15 are associated with histologic progression in follicle center lymphoma. Blood 91:4677-4685.

Falini B, Fizzotti M, Pucciarini A, Bigerna B, Marafioti T, Gambacorta M, Pacini R, Alunni C, Natali-Tanci L, Ugolini B, Sebastiani C, Cattoretti G, Pileri S, Dalla-Favera R, and Stein $H$ (2000). A monoclonal antibody (MUM1p) detects expression of the MUM1/IRF4 protein in a subset of germinal center B cells, plasma cells, and activated T cells. Blood 95:20842092.

Freeman GJ, Long AJ, Iwai $\mathrm{Y}$, Bourque $\mathrm{K}$, Chernova $\mathrm{T}$, Nishimura H, Fitz LJ, Malenkovich N, Okazaki T, Byrne MC, Horton HF, Fouser L, Carter L, Ling V, Bowman MR, Carreno BM, Collins M, Wood CR, and Honjo T (2000). Engagement of the PD-1 immunoinhibitory receptor by a novel B7 family member leads to negative regulation of lymphocyte activation. J Exp Med 192:1027-1034.

Fry AM (2002). The Nek2 protein kinase: A novel regulator of centrosome structure. Oncogene 21:6184-6194.

Fry AM, Meraldi P, and Nigg EA (1998). A centrosomal function for the human Nek2 protein kinase, a member of the NIMA family of cell cycle regulators. EMBO J 17:470-481.

Fry AM, Schultz SJ, Bartek J, and Nigg EA (1995). Substrate specificity and cell cycle regulation of the Nek2 protein kinase, a potential human homolog of the mitotic regulator NIMA of Aspergillus nidulans. J Biol Chem 270:1289912905.

Goff LK, Neat MJ, Crawley CR, Jones L, Jones E, Lister TA, and Gupta RK (2000). The use of real-time quantitative polymerase chain reaction and comparative genomic hybridization to identify amplification of the REL gene in follicular lymphoma. Br J Haematol 111:618-625.

Grogan TM, Rangel CS, Rimsza L, Bellamy W, Martel R, McDaniel D, McGraw B, Richards W, Richter L, Rodgers P, Rybski JA, Showalter W, Vela E, and Zeheb R (1995). Kinetic-mode, automated double-labeled immunohistochemistry and in-situ hybridization in diagnostic pathology. Adv Pathol Lab Med 8:79-100.

Hofmann WK, de Vos S, Tsukasaki K, Wachsman W, Pinkus GS, Said JW, and Koeffler HP (2001). Altered apoptosis pathways in mantle cell lymphoma detected by oligonucleotide microarray. Blood 98:787-794.

Horning SJ (1994). Low-grade lymphoma 1993: State of the art. Ann Oncol 5:23-27.

Horning SJ (2000). Follicular lymphoma: Have we made any progress? Ann Oncol 11:23-27.

Houldsworth J, Mathew S, Rao PH, Dyomina K, Louie DC, Parsa N, Offit K, and Chaganti RS (1996). REL protooncogene is frequently amplified in extranodal diffuse large cell lymphoma. Blood 87:25-29. 
Huang JZ, Sanger WG, Greiner TC, Staudt LM, Weisenburger DD, Pickering DL, Lynch JC, Armitage JO, Warnke RA, Alizadeh AA, Lossos IS, Levy R, and Chan WC (2002). The $t(14 ; 18)$ defines a unique subset of diffuse large B-cell lymphoma with a germinal center B-cell gene expression profile. Blood 99:2285-2290.

lida S, Rao PH, Butler M, Corradini P, Boccadoro M, Klein B, Chaganti RS, and Dalla-Favera R (1997). Deregulation of MUM1/IRF4 by chromosomal translocation in multiple myeloma. Nat Genet 17:226-230.

lijima $Y$, Ito T, Oikawa T, Eguchi M, Eguchi-Ishimae M, Kamada N, Kishi K, Asano S, Sakaki Y, and Sato Y (2000). A new ETV6/TEL partner gene, ARG (ABL-related gene or $A B L 2)$, identified in an AML-M3 cell line with a $t(1 ; 12)(q 25$; p13) translocation. Blood 95:2126-2131.

Ishida Y, Agata Y, Shibahara K, and Honjo T (1992). Induced expression of PD-1, a novel member of the immunoglobulin gene superfamily, upon programmed cell death. EMBO J 11:3887-3895.

Jaffe ES, Banks PM, Nathwani B, Said J, and Swerdlow SH (2002). Recommendations for the reporting of lymphoid neoplasms. A report from the Association of Directors of Anatomic and Surgical Pathology. Hum Pathol 33:10641068.

Johansson B, Mertens F, and Mitelman F (1995). Cytogenetic evolution patterns in non-Hodgkin's lymphoma. Blood 86: 3905-3914.

Joos S, Otano-Joos MI, Ziegler S, Bruderlein S, du Manoir S, Bentz M, Moller P, and Lichter P (1996). Primary mediastinal (thymic) B-cell lymphoma is characterized by gains of chromosomal material including $9 p$ and amplification of the REL gene. Blood 87:1571-1578.

Junn E, Han SH, Im JY, Yang Y, Cho EW, Um HD, Kim DK, Lee KW, Han PL, Rhee SG, and Choi I (2000). Vitamin D3 up-regulated protein 1 mediates oxidative stress via suppressing the thioredoxin function. J Immunol 164:62876295.

Kaback DB and Feldberg LR (1985). Saccharomyces cerevisiae exhibits a sporulation-specific temporal pattern of transcript accumulation. Mol Cell Biol 5:751-761.

Knutsen T (1997). Cytogenetic mechanisms in the pathogenesis and progression of follicular lymphoma. Cancer Surv 30:163-192.

Kossakowska AE, Edwards DR, Prusinkiewicz C, Zhang MC, Guo D, Urbanski SJ, Grogan T, Marquez LA, and JanowskaWieczorek A (1999). Interleukin-6 regulation of matrix metalloproteinase (MMP-2 and MMP-9) and tissue inhibitor of metalloproteinase (TIMP-1) expression in malignant nonHodgkin's lymphomas. Blood 94:2080-2089.

Kossakowska AE, Urbanski SJ, Watson A, Hayden LJ, and Edwards DR (1993). Patterns of expression of metalloproteinases and their inhibitors in human malignant lymphomas. Oncol Res 5:19-28.

Kruh GD, King CR, Kraus MH, Popescu NC, Amsbaugh SC, McBride WO, and Aaronson SA (1986). A novel human gene closely related to the abl proto-oncogene. Science 234 : 1545-1548.

Kruh GD, Perego R, Miki T, and Aaronson SA (1990). The complete coding sequence of arg defines the Abelson subfamily of cytoplasmic tyrosine kinases. Proc Natl Acad Sci USA 87:5802-5806.
Kubota T, Miyauchi M, Miura K, Hirokawa G, Awaya A, Miyasaka N, Kurosawa Y, Kanai Y, and Maruyama K (1998). Upregulation of nucleobindin expression in human-activated lymphocytes and non-Hodgkin's lymphoma. Pathol Int 48: 22-28.

Limpens J, Stad R, Vos C, de Vlaam C, de Jong D, van Ommen GJ, Schuuring E, and Kluin PM (1995). Lymphomaassociated translocation $t(14 ; 18)$ in blood $B$ cells of normal individuals. Blood 85:2528-2536.

Lin P, Fischer T, Weiss T, and Farquhar MG (2000). Calnuc, an EF-hand $\mathrm{Ca}(2+)$ binding protein, specifically interacts with the C-terminal alpha5-helix of G(alpha)i3. Proc Natl Acad Sci USA 97:674-679.

Lo Coco F, Gaidano G, Louie DC, Offit K, Chaganti RS, and Dalla-Favera R (1993). p53 mutations are associated with histologic transformation of follicular lymphoma. Blood 82: 2289-2295.

Lossos IS, Alizadeh AA, Diehn M, Warnke R, Thorstenson Y, Oefner PJ, Brown PO, Botstein D, and Levy R (2002). Transformation of follicular lymphoma to diffuse large-cell lymphoma: Alternative patterns with increased or decreased expression of c-myc and its regulated genes. Proc Natl Acad Sci USA 99:8886-8891.

Masutani H and Yodoi J (2002). Thioredoxin: Overview. Methods Enzymol 347:279-286.

Matolcsy A, Casali P, Warnke RA, and Knowles DM (1996). Morphologic transformation of follicular lymphoma is associated with somatic mutation of the translocated $\mathrm{Bcl}-2$ gene. Blood 88:3937-3944.

Matolcsy A, Schattner EJ, Knowles DM, and Casali P (1999). Clonal evolution of B cells in transformation from low- to high-grade lymphoma. Eur J Immunol 29:1253-1264.

McDonnell TJ and Korsmeyer SJ (1991). Progression from lymphoid hyperplasia to high-grade malignant lymphoma in mice transgenic for the $\mathrm{t}(14 ; 18)$. Nature 349:254-256.

Miura K, Titani K, Kurosawa Y, and Kanai Y (1992). Molecular cloning of nucleobindin, a novel DNA-binding protein that contains both a signal peptide and a leucine zipper structure. Biochem Biophys Res Commun 187:375-380.

Nishimura H, Nose M, Hiai H, Minato N, and Honjo T (1999). Development of lupus-like autoimmune diseases by disruption of the PD-1 gene encoding an ITIM motif-carrying immunoreceptor. Immunity 11:141-151.

Nishimura H, Okazaki T, Tanaka $\mathrm{Y}$, Nakatani K, Hara M, Matsumori A, Sasayama S, Mizoguchi A, Hiai H, Minato N, and Honjo T (2001). Autoimmune dilated cardiomyopathy in PD-1 receptor-deficient mice. Science 291:319-322.

Nishiyama A, Matsui M, Iwata S, Hirota K, Masutani $H$, Nakamura H, Takagi Y, Sono H, Gon Y, and Yodoi J (1999). Identification of thioredoxin-binding protein-2/vitamin $\mathrm{D}(3)$ up-regulated protein 1 as a negative regulator of thioredoxin function and expression. J Biol Chem 274:21645-21650.

Nomdedeu JF, Baiget M, Gaidano G, Estivill C, Lasa A, Rubiol E, Mateu R, Bordes R, Brunet S, Saglio G, and Soler $J$ (1998). p53 mutation in a case of blastic transformation of follicular lymphoma with double bcl-2 rearrangement (MBR and VCR). Leuk Lymphoma 29:595-605.

Okuda K, Weisberg E, Gilliland DG, and Griffin JD (2001). ARG tyrosine kinase activity is inhibited by STI571. Blood 97:2440-2448. 
Ottensmeier $\mathrm{CH}$, Thompsett AR, Zhu D, Wilkins BS, Sweetenham JW, and Stevenson FK (1998). Analysis of VH genes in follicular and diffuse lymphoma shows ongoing somatic mutation and multiple isotype transcripts in early disease with changes during disease progression. Blood 91:42924299.

Pinyol M, Cobo F, Bea S, Jares P, Nayach I, Fernandez PL, Montserrat E, Cardesa A, and Campo E (1998). p16(INK4a) gene inactivation by deletions, mutations, and hypermethylation is associated with transformed and aggressive variants of non-Hodgkin's lymphomas. Blood 91:2977-2984.

Primig M, Williams RM, Winzeler EA, Tevzadze GG, Conway AR, Hwang SY, Davis RW, and Esposito RE (2000). The core meiotic transcriptome in budding yeasts. Nat Genet 26:415423.

Rajeevan MS, Vernon SD, Taysavang N, and Unger ER (2001). Validation of array-based gene expression profiles by real-time (kinetic) RT-PCR. J Mol Diagn 3:26-31.

Rao PH, Houldsworth J, Dyomina K, Parsa NZ, Cigudosa JC, Louie DC, Popplewell L, Offit K, Jhanwar SC, and Chaganti RS (1998). Chromosomal and gene amplification in diffuse large B-cell lymphoma. Blood 92:234-240.

Sander CA, Yano T, Clark HM, Harris C, Longo DL, Jaffe ES, and Raffeld M (1993). p53 mutation is associated with progression in follicular lymphomas. Blood 82:1994-2004.

Stamatopoulos K, Kosmas C, Belessi C, Stavroyianni N, Kyriazopoulos P, and Papadaki T (2000). Molecular insights into the immunopathogenesis of follicular lymphoma. Immunol Today 21:298-305.

Stranks G, Height SE, Mitchell P, Jadayel D, Yuille MA, De Lord C, Clutterbuck RD, Treleaven JG, Powles RL, Nacheva $\mathrm{E}$, et al. (1995). Deletions and rearrangement of CDKN2 in lymphoid malignancy. Blood 85:893-901.

Strasser A, Harris AW, Bath ML, and Cory S (1990). Novel primitive lymphoid tumours induced in transgenic mice by cooperation between myc and bcl-2. Nature 348:331-333.

Tilly $H$, Rossi A, Stamatoullas A, Lenormand B, Bigorgne C, Kunlin A, Monconduit M, and Bastard C (1994). Prognostic value of chromosomal abnormalities in follicular lymphoma. Blood 84:1043-1049.
Toledano MB and Leonard WJ (1991). Modulation of transcription factor NF-kappa B binding activity by oxidationreduction in vitro. Proc Natl Acad Sci USA 88:4328-4332.

Traweek ST, Liu J, Johnson RM, Winberg CD, and Rappaport H (1993). High-grade transformation of chronic lymphocytic leukemia and low-grade non-Hodgkin's lymphoma: Genotypic confirmation of clonal identity. Am J Clin Pathol 100: $519-526$

Tsuboi K, lida S, Inagaki H, Kato M, Hayami Y, Hanamura I, Miura K, Harada S, Kikuchi M, Komatsu H, Banno S, Wakita A, Nakamura S, Eimoto T, and Ueda R (2000). MUM1/IRF4 expression as a frequent event in mature lymphoid malignancies. Leukemia 14:449-456.

Wai DH, Schaefer KL, Schramm A, Korsching E, Van Valen F, Ozaki T, Boecker W, Schweigerer L, Dockhorn-Dworniczak B, and Poremba C (2002). Expression analysis of pediatric solid tumor cell lines using oligonucleotide microarrays. Int $\mathrm{J}$ Oncol 20:441-451.

Weiss LM and Warnke RA (1985). Follicular lymphoma with blastic conversion: A report of two cases with confirmation by immunoperoxidase studies on bone marrow sections. Am J Clin Pathol 83:681-686.

Wellmann A, Thieblemont C, Pittaluga S, Sakai A, Jaffe ES, Siebert $P$, and Raffeld M (2000). Detection of differentially expressed genes in lymphomas using cDNA arrays: Identification of clusterin as a new diagnostic marker for anaplastic large-cell lymphomas. Blood 96:398-404.

Yano T, Jaffe ES, Longo DL, and Raffeld M (1992). MYC rearrangements in histologically progressed follicular lymphomas. Blood 80:758-767.

Yuen AR, Kamel OW, Halpern J, and Horning SJ (1995). Long-term survival after histologic transformation of lowgrade follicular lymphoma. J Clin Oncol 13:1726-1733.

Zelenetz AD, Chen TT, and Levy R (1991). Histologic transformation of follicular lymphoma to diffuse lymphoma represents tumor progression by a single malignant B cell. J Exp Med 173:197-207. 